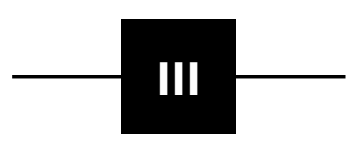

ARTICLES

\title{
State Legibility and Mind Legibility in the Original Political Society
}

\author{
Natalia Buitron and Hans Steinmüller
}

ABSTRACT: In one of his last great provocations, Marshall Sahlins describes the 'original political society' as a society where supposedly 'egalitarian' relations between humans are subordinated to the government of metahuman beings. He argues that this government is 'a state', but what kind of state does he mean? Even if metahumans are hierarchically organized and have power over human beings, they lack two capacities commonly attributed to political states: systematic means to make populations legible and coercive means to identity the intentions of others. The nascent forms of state legibility and public mind reading that are present in Sahlins's original political society are not unified and tied to particular agents. A discussion of the limitations of state and mind legibility points to the fundamental correlations between those two forms of legibility and their co-implication in whatever might be called 'the state'.

KEYWORDS: animism, metahuman, mind reading, opacity, state, state legibility

For many students of anthropology, reading "The Original Affluent Society" was a conversion experience. Marshall Sahlins's (1972) argument fundamentally changed how anthropologists understood 'primitive' economic life. Rather than 'nasty, brutish, and short', the lives of hunter gatherers were full of abundance and leisure. To adopt a truly anthropological perspective we had to drop core assumptions of modern Western thought, such as the dismal combination of unlimited wants and scarce means. "The Original Affluent Society" thus stands for the fundamental turn of perspectives that is the benchmark of anthropology. In his recent essay "The Original Political Society," Sahlins (2017b) calls for another fundamental turn of perspectives: the cosmos is not governed by human society, but by metahuman beings. The societies that anthropologists commonly call 'egalitarian' are hierarchically encompassed by owners, spirits, and gods. More powerful than ordinary humans, such beings govern birth and death, luck and misfortune, the seasons and the weather. The rule of metahuman beings is similar to a 'state' and a 'rule of law', for "something like the political state is the condition of humanity in the state of nature; there are kingly beings in heaven even where there are no chiefs on earth" (ibid.: 91). 
This playful inversion of terms hinges on a crucial question left unmentioned: what kind of state is the state of the 'original political society' (OPS, henceforth)?

As far as we can tell, the myriad spirits in so many ethnographies of so-called egalitarian societies $^{1}$ are indeed tremendously powerful and unavoidably present. However, their rule appears to lack two core features that are sine qua non prerequisites for a political state among human beings: the capacity of the government to make populations legible and the capacity of the governed to make minds legible. This is perhaps simply stating the obvious: the societies that are examples of the OPS are typically oral societies. But even though literacy is commonly seen as a core requirement for state building (Wang 2014), it is not indispensable for state legibility. State legibility can be created by simplifying and unifying certain external features of a population, such as planting crops in a row, for example. The capacity to read other minds similarly does not require literacy: to the contrary, mind reading is a universal feature of the human condition without which language and social interaction would be inconceivable.

Even in the OPS there might be some mediated simplification of populations (which could turn into state legibility), and there certainly is ordinary mind reading. But however populations and minds are 'read' in such a society, this reading cannot be systematized and unified into one central perspective. The centralization of perspectives that is essential to state legibility and centralized, public mind reading (i.e., mind legibility) is impeded because of the absence of sedentary agriculture and writing that, in turn, enable the rise of the state (as commonly understood), with institutions such as bureaucracies, legal systems, and schools, which further enhance legibility by disciplining populations, centralizing the public apportioning of responsibility, and enforcing collective judgments.

Beyond those constraints to legibility, which make it difficult for intentions to become publicly available, debated, and shared, there are also positive reasons for keeping intentions opaque that have to do with the lifestyles, practices, and cosmologies of decentralized societies. If there are any individuals in the OPS who exhibit extraordinary capacities to read wider populations and the minds of others (typically shamans and sorcerers), they lack the power (or desire) to codify and centralize their knowledge about others. These specialists exercise power through individual performance rather than through their exclusive mastery of a sacred tradition. Shamanism thus remains inconsistent with a centralizing ideology, and hence with state formation.

Yet if state legibility and public mind reading are limited in this world, are they perhaps available to the metahumans, the source of government in the OPS? To anticipate our main argument, the answer is a resounding no. Not only humans, but even the metahumans of the OPS refrain from making others fully legible. The members of such societies do not separate sociology from cosmology and do not make a categorical distinction between the communication that can take place between humans and the communication with metahumans. Correspondingly, what applies to humans also applies to metahumans: neither can centralize perspectives in the manner required for state legibility or systematize mind reading to make other minds publicly available. Even so, asking the question of legibility in relation to the OPS-fundamentally, can the metahuman read? - raises a whole series of interesting questions about state legibility, mind reading, and the nature of 'the state' everywhere.

Our discussion of state legibility and mind legibility challenges the idea that the government of metahumans resembles a 'state'. We briefly introduce Sahlins's idea and contrast it with James Scott's writings about state legibility and with anthropological arguments about mind legibility (to do with the opacity of mind doctrines and public mind reading). This leads us to our core question: what can we learn about non-state government seen from the perspective of state and mind legibility? We will explore these issues by looking closely at the relations between humans and metahumans, specifically as they present themselves in the literature on 
Amazonian shamans and species-owners. We discuss the limits of legibility in Amazonia and, by extension, in the OPS in general. On this basis, we qualify Sahlins's argument about the nature of the state and the government of non-humans. Additionally, we point toward some fundamental correlations between state legibility and public mind reading, which we have explored in detail elsewhere (Buitron and Steinmüller, forthcoming).

\section{The OPS}

Delivered as the first Hocart Lecture at the School of Oriental and African Studies in 2016, the OPS ${ }^{2}$ is the last high point in the work of Marshall Sahlins. In the lecture, Sahlins (2017b) returns to Hocart's classical question of the origins of human government in ritual. But instead of dealing with the transition from ritual to kingship, he elaborates on Hocart's first hypothesis: prior to any form of human government, there is the government of the cosmos. On the basis of classical and recent references from the ethnographic record, Sahlins argues that the cosmopolitics of so-called stateless societies already exhibit hierarchies, rules, and government, that is, features of social life that are commonly described as a 'state'. His argument builds on the work of Philippe Descola, who suggests in his magnum opus Beyond Nature and Culture (2013) that instead of one Cartesian opposition between thinking mind and dead matter, there are four ontological modes that rely on the four possible combinations of continuity/discontinuity and interiority/physicality. In the foreword to the English translation of Descola's book, Sahlins (2013: xiii) points to some of the major consequences of Descola's "neo-Copernican claim" that 'nature' only became mindless matter since the triumph of naturalism in the West in the last few hundred years, and for this reason notions such as the "supernatural" and "production" will have to be revised when dealing with worlds in which 'nature' does not exist. Sahlins discusses some of these revisions in another essay (2014) in which he subsumes animism, totemism, and analogism under a generalized notion of animism and subordinates it to semi-universal anthropomorphism. Perhaps in their most concise form, the consequences of Sahlins's engagement with Descola are stated as Nietzschean prolegomena in On Kings (Graeber and Sahlins 2017a: 2):

Human societies are hierarchically encompassed-typically above, below, and on earth—in a cosmic polity populated by beings of human attributes and metahuman powers who govern the people's fate. In the form of gods, ancestors, ghosts, demons, species-masters, and the animistic beings embodied in the creatures and features of nature, these metapersons are endowed with far-reaching powers of human life and death, which, together with their control of the conditions of the cosmos, make them the all-round arbiters of human welfare and illfare. Even many loosely structured hunting and gathering peoples are thus subordinated to beings on the order of gods ruling over great territorial domains and the whole of the human population. There are kingly beings in heaven even where there are no chiefs on earth.

Graeber and Sahlins (2017a: 3) conclude: "It follows that the state of nature has the nature of the state. Given the governance of human society by metaperson authorities with ultimate lifeand-death powers, something quite like the state is a universal human condition." The 'state' of the OPS is built upon some unavoidable facts of human life: humans are mortal and subject to the animated forces of nature, in particular the weather and the seasons. The 'state' prior to any form of centralized government or rule of law among human beings is present as a hierarchy of metabeings such as the sun and the moon, the stars and the rain, and countless others. The lives 
of people in non-hierarchical and 'stateless' societies are governed by a plethora of rulers and rules that are beyond the control of ordinary humans.

We want to dwell on the implications of what is perhaps simply a slippage in Sahlins's argument: from the inevitability and mighty power of metahuman beings to the state and the rule of law. We do this from the perspective of state legibility. Do metahuman beings have the power to see, read, and govern populations? Is there anything like state legibility in the government of metahuman beings?

\section{State Legibility}

Since Seeing Like a State, James Scott (1998) has argued that states need to make populations legible so as to be able to achieve the fundamental objectives of statecraft, that is, taxation, conscription, and pacification. He describes and analyzes a number of means that radically simplify and map social reality to create state legibility: permanent family surnames, language standardization, sedentarization, urban planning, and grain agriculture. While Seeing Like a State deals mainly with the last few hundred years and high-modernist states in particular, in his recent book Against the Grain, Scott (2017) extends his study of state legibility to the earliest states. Mainly dealing with examples from Mesopotamia, he demonstrates that the earliest states equally relied on the capacity to create state legibility. Aside from sedentism and writing, it was in particular the cultivation of millets and cereal grains that served this purpose. These particular grains are relatively visible: they are easy to quantify, harvest, and store, and for the same reasons can be managed relatively easily by the authorities. Tubers are the opposite: they are less visible and quantifiable and more difficult to harvest. Hence, these were generally the crops of choice for the 'escape populations' outside the reach of the states (Scott 2009). In his later work, Scott makes very clear that particular means of state legibility (such as grains or cities) were never steps on an evolutionary ladder or part of an 'agricultural package' - the idea that agriculture inevitably comes together with centralizing states. To the contrary, he emphasizes all kinds of historical twists and unintended effects of projects of legibility, produced, for instance, by crowding and disease. State legibility in Scott's sense is therefore important to us, not because of its evolutionism (it could be only in bad faith), but because of its bona fide insight: any centralization of power (=state) requires a centralization of perspectives (=state legibility).

In Scott's argument, state officials tasked with creating and maintaining state legibility generally tend to neglect the practical knowledge (the metis) of the commoners. For the same reason, many state projects that overachieve ultimately fail. Yet what Scott ignores is how, exactly, both the knowledge of state officials and of ordinary people changes in the process. Below we explore the proposition that with the increase of methods for creating state legibility in a given population, the question of how to make other minds legible, or publicly available for inspection, will become progressively prominent in the same population. Another problem that lies outside Scott's purview is the government of the metahumans. The Jade Emperor in China and the Catholic God of rural Spain, for instance, clearly possess the means to make populations legible in ways that are very similar to worldly bureaucracies and empires (see, e.g., Christian 1989; Feuchtwang 2001). But what about the metahuman governors of the OPS? We explore this question below for the case of Amazonian owners and shamanism.

Admittedly, the means to create state legibility that James Scott has described are fundamentally tools to manage information about people, not tools to make intentions and private states legible or publicly available. But it is perhaps not a coincidence that the technologies that increase state legibility (census, register, bureaucracy, etc.) often correlate with a systematization of mind 
reading. We explore this proposition in two steps. First, the ability to read other minds is universal, but this ability is de-emphasized in decentralized and so-called stateless societies. In these societies, in fact, as we explain below, an opacity of mind doctrine prevails; not even metahumans (or those who master relations with them) can make others fully legible or subdue their intentions. In these societies, asymmetric relations between metahumans and humans do not translate into a unification and centralization of perspectives, which would be necessary to systematize mind legibility and to create state legibility. Second, because the creation of state legibility is always a mutual project (even though this might be ignored or downplayed by the government), it correlates with the necessity to understand the intentions of co-residents and strangers.

\section{Mind Legibility and Opacity of Mind}

Although telepathy is impossible, humans attribute thoughts, desires, and beliefs to others all the time. Since the 1980s, the question of how humans begin to attribute intentions and beliefs to the minds of others as a way of explaining their behavior has become known as the problem of 'theory of mind' (e.g., Astington 2006; Wellman et al. 2001). Theory of mind refers to the idea that the ability to explain and predict behavior via mental states is underpinned "by a folk-psychological theory of the structure and functioning of the mind" (Carruthers and Smith 1996: 1). ${ }^{3}$ The ability in question appears to be universal in human beings ${ }^{4}$ and matures at least from about four to five years of age. But its universality depends on the definitions given to 'theory' and to 'mind', and, relatedly, to the nature of intentionality: it is possible that a fully fledged and explicit theoretical perspective on specific minds that are the seat of intentions is not necessary to anticipate the actions of others. Some anthropologists have been particularly skeptical about the emphasis on individual intentions (e.g., Keane 2016: 118), while others have proposed alternative 'theories of mind' (see discussions in Luhrmann 2020; Luhrmann et al. 2011). Typically, they acknowledge cognitive universals, such as the basic capacity to conceive of the minds of others, and then add further cultural variations, for example, different forms in which this basic capacity is expressed and developed in different societies (cf. Astuti 2012). But rather than opposing 'universal theory' with a 'cultural particular', a focus on the social uses and meanings of intentionality is particularly useful for our purposes here. The question about the relative public availability of intentions, their desired transparency, and whether they are amenable to control is at the heart of the debates about 'opacity doctrines' in anthropology.

Particularly important in this field has been the collection titled "Cultural and Linguistic Anthropology and the Opacity of Other Minds," with an introduction by Robbins and Rumsey (2008). The contributors argue that many Pacific peoples appear disinclined to mind-read in public and routinely disavow knowledge of the mental states of others as a way to interpret behavior and attribute responsibility for actions. Robbins, Rumsey, and others identify this prohibition to speak about other minds and intentions in public as the doctrine of the opacity of other minds', or in brief, 'opacity doctrine'. The empirical grounds for asserting the existence of society-wide opacity doctrines is often simply everyday talk, and several authors have called for methodological caution in this regard. Even where there are explicit prohibitions against public mind reading, most social actors everywhere anticipate others' actions and impute intentions and desires. Opacity doctrines, therefore, do not refer to the complete absence of intentions and mind reading, but instead should be understood as "metalinguistic and metapragmatic claims about the relations between public evidence and private states" (Keane 2008: 474). As such, the requirement and/or desire for opacity should be seen within the confines of particular linguistic codes, which allow for the expression of inner states in particular ways, as well as the specific 
pragmatics of a situation. In this sense, opacity doctrines may embody political models, for instance, those that have to do with core values and social distinctions. This point is brought home by Rupert Stasch's (2008) essay "Knowing Minds Is a Matter of Authority," in which he shows that the Korowai of West Papua avoid talking about the intentions of others so as not to interfere with their autonomy and self-determination.

In recent debates on the issue, a promising line of interpretation relates considerations about the degree to which interiority matters to local attitudes toward authority and accountability, while considering how the use of intentional language often reflects a form of social control over the shape and expression of such an interiority. There is evidence that in the Pacific and in Amazonia, for instance, the act of making public one's speculations about others' mental activity makes speakers particularly anxious about external control, and this is why ordinary people often refrain from presuming to know other minds, giving orders, and making public accusations. This may partly be what Pierre Clastres (1989) had in mind when he suggested that rather than trying to understand 'stateless' societies as lacking in power, we should understand them as standing against a certain kind of power, namely, the 'command-obedience' relationship, which is usually taken for granted in state societies. But even in stratified and hierarchical societies, anthropologists have described the same doctrines, for example, as in Samoa (Duranti 2008), or phenomena approximating a prohibition on public mind reading, for instance, 'mistrust' in North Africa (Carey 2017) or 'social opacity' in Chiapas (Groark 2008). If elsewhere opacity promotes autonomy against social control, in societies where group identity, prescribed roles, and social obligation are firmly established, opacity tends to reinforce social control over individual autonomy (cf. Duranti 2015: 241). In both cases, the disavowal of intentional discourse could be interpreted as "a defense strategy against the accountability that comes with making claims about what others think or want" (Duranti 2008: 492-493; see also Danziger 2013: 260). In this view, the opacity doctrine could ultimately imply a "pan-human preoccupation with reducing one's accountability" (Duranti 2008: 493). If the prevalence of opacity doctrines is based on a concern for autonomy (and resistance to accountability), which factors might shape this concern? We argue that techniques of legibility and processes of state formation are central: in other words, state legibility ultimately promotes mind legibility. Legibility in both cases means that relations of accountability and power can be established in the interest of government. Mind legibility refers to public mind reading, the possibility and even requirement that interior states are publicly discussed, compared, and evaluated, thereby creating the illusion that opacity can be overcome. Thus, the relations of opacity we can find in the absence of state legibility (e.g., in pre-missionized Amazonia) are fundamentally different from those that are mobilized to hide from contemporary governments, for instance. Below we will outline some of the main correlations between state and mind legibility that allow for 'governing opacity', a topic we analyze in much more depth elsewhere (Buitron and Steinmüller, forthcoming). Having briefly considered state legibility and public mind reading, we note that both seem to be absent from the OPS. What can we say about legibility in the societies Sahlins described? Specifically, in the relations between humans and metahumans?

\section{Human-Metahuman Relations in the OPS}

An opacity of minds pervades interactions between ordinary humans, but does this opacity extend to interactions between humans and metapersons? Sahlins's anti-Cartesian framework would lead us to suppose exactly this-a framework he shares with most ethnographers working in the societies of the OPS. Despite the asymmetries between humans and metahumans, 
both share the same kind of subjectivity. This is in fact a core feature of animism, as described by Descola and many others: a sharp distinction is not drawn between the socio-cultural world of humans and the socio-cultural world of plants, animals, and spirits, who are viewed as sentient, intentional subjects. This means that just as there is no natural realm distinct from the human, there is no supernatural realm distinct from nature.

According to Descola's (2013) influential outline, in animism there is no fundamental qualitative difference between humans and non-humans: both share a continuous interiority, and both are distinguished by discontinuous physicality. In Descola's view, the relational schemas that organize relations in different socio-cosmic collectives can be distinguished according to the extent to which the parties of the relation share or do not share the same ontological status. In line with this, the relational schemas that govern connections within animistic collectives are exchange (or reciprocity), gift (or sharing), and predation. Importantly, all three schemas are characterized by potentially reversible relations between terms that are similar, even if the relations between them are at times asymmetric (as is the case of predation). By contrast, relations of production, protection, and transmission, which are less dominant in animistic collectives, "involve univocal relations that are founded upon connections between non-equivalent terms" (Descola 2012: 448-449). Costa and Fausto (2019) have recently proposed a fundamental corrective to this ontological and relational matrix, arguing that in Amazonia there is a way to convert predation into protection (a relation between non-equivalent terms). This is possible through mastery (or ownership), a dynamic schema that articulates modes of capturing (predation), generating a movement called 'familiarizing predation' or adoption, ${ }^{5}$ whereby symmetric relations of enmity or capture are converted into asymmetric relations of kinship. This is how masters or owners emerge. We shall see that even asymmetric relations of mastery that create protection are fundamentally dispersive and thus pre-empt the forms of hierarchization and unification required to establish legibility.

Perhaps it is not necessary to decide on the ontological status or (non-)equivalence of humans and non-humans, if only it is possible to show that the system of communication is continuous: Guido Sprenger (2017), for instance, demonstrates exactly that for the case of the interactions between Rhmeet uplanders in Laos with agricultural spirits. He argues that the same principles of communication decide on the ascription of personhood, no matter whether the being in question is human or non-human, or otherwise seen as ontologically different. In cases in which an opacity doctrine regulates behavior among humans, it likely also regulates the interactions between humans and metahuman beings.

This point can be illustrated by comparing the relations of production that prevail in naturalistic collectives and the relations of sharing/exchange/predation or even protection that regulate commerce between humans and non-humans in animistic collectives. Following Descola (2013: 321), production is a relational schema that emphasizes the radical difference between the ontological status of the creator and what s/he brings into being. Accordingly, relations of production involve "the imposition of form upon inert matter" whereby "an individualized intentional agent" - whether a god, a demiurge, or a simple mortal-is the cause of the coming-to-be of other beings or things (ibid.: 323). In animistic collectives, by contrast, there are no creators, and it does not make sense to describe hunting or gardening there as 'production. Instead, people establish personal relations with the plants they cultivate, the animals they hunt, and the spirits on which they depend. Often in fact, relations between humans and metahumans involve direct contact, and this directness (not to be confused with the absence of power or with intentional transparency) is connected with a conception of non-humans as being similar in essence to the soul of humans, a belief that moreover distinguishes nonhumans from gods (see Hamayon 1996: 78). 
In the case of the Amazonian Achuar, who first inspired Descola's (2012) thinking about animism, to regenerate their livelihoods, women must speak to each of their plants so as to touch their souls and thereby win them over, favor their growth, and help them survive the perils of life. Similarly, Achuar men negotiate with the animals they hunt, and they do so personally, in a "circumspect relationship made up of cunning and seduction, trying to beguile them with misleading words and false promises" (ibid.: 459). In other words, the relations that humans cultivate with non-humans on whom they fundamentally rely for their subsistence depend on the skilled management of affections and desires. And while this management ultimately aims at influencing the internal states of powerful others through all sorts of techniques-from direct contact to complex affective exchanges such as garden and hunting magic and the specialized healing, divining, and prophesying more typical of shamanic commerce-these interactions take place between beings who can never entirely control or fully read each other's intentions and thus the cunning, seduction, and ambivalence that these interactions often involve. Crucially, this effort at aligning and influencing the intentions of others goes both ways: the metahumans, too, strive to win the favors of or avoid the harms caused by humans, and the intentions and affects of humans are neither fully known nor liable to total metahuman control. The interpretive labor between humans and metahumans is therefore mostly reciprocal. ${ }^{6}$ Often enough, in fact, and especially in animistic collectives where a predatory relational schema prevails, exchanges between all living things resemble a battle for vitality. To reproduce one's kinfolk, one must prey upon other social beings; the animals and spirits give, but they must also take back, sooner or later.

As mentioned, Sahlins's (2015: 11) argument is that people living in typically non-state political formations have "always known inequality as a condition of their social condition" by virtue of their dependence on metahumans, that is, superhuman potencies such as spirits, gods, marvelous beasts, or powerful foreigners. We would like to dispute the nature of this inequality on the grounds that it overlooks central features of the relation between humans and metahumans and, most importantly, the fundamental instability that characterizes it. As we shall see, while the relation between the two terms is often one of asymmetry, it does not have the stability necessary to qualify or consolidate as absolute or apical power to the advantage of metahumans. By drawing attention to the potency of the metahuman, Sahlins obviates the power of the human and the directional inversions that often occur between the two terms. For these terms to constitute a relation-and it is the relation rather than the ontological category that matters (see, e.g., Déléage 2005: 191; Fausto 2008: 2, 4) —the dependent agent must also be powerful enough to sustain the relation. It is this power that creates a positional instability.

To illustrate this point, we briefly explore one iteration of the metaperson in animistic Amazonia, for this is one of the ethnographic sources that inspired Sahlins's model. One of the most pervasive and important categories of beings in Amazonia is the figure of the 'owner' or 'master', which corresponds to what Åke Hultkrantz (1961) termed 'the supernatural owners of nature'. Owner-masters preside over different species of animals, plants, and artifacts. Carlos Fausto (2008) has theorized the 'mastery-ownership relation' at length; owner-masters create an intrinsically asymmetric relation via adoptive filiation in a variety of ordinary and ritual contexts (only some of which involve interspecific relations): shaman/auxiliary spirits, chiefs/followers, adoptive parent/child, warrior captor/captive child, master/pet, killer/victim, and so forth.

Anything that Euro-Americans call 'nature' can have an owner. Referencing Descola, Fausto (2008: 10) asserts that "nature is domestic because it is always the domus of someone." But while this makes it difficult to imagine the existence of autonomous or neutral domains, the world does not resemble a fixed and definitive "cosmic cartography of discrete and exclusive properties" (ibid.: 11; see also Costa and Fausto 2019: 205) as would, for example, the territories of a state. In other words, dominium should not be confused with domination. In keeping with the fundamental 
instability that characterizes some animist collectives, we would like to mention at least two more specific reasons for this. The first is that relations of mastery-ownership are fundamentally dispersive - that is, they follow a multiplicatory and non-totalizing logic. As Costa and Fausto (2019: 203) have recently put it, there always are "too many owners," and rarely if ever is there "One over the Many," a master who "towers above all others." The world of masters is not "conical" but rather a "sea of hills" (ibid.: 204). The multiplicatory logic of mastery-ownership relations curtails the crystallization of power because it prevents the hierarchization of owner positions into a stable ranked structure or institutional locus. Thus, for the most part, owner-masters do not constitute a stable structure center or vantage point of view from which to watch over and control all the creatures of the world. ${ }^{7}$ For this reason, it is commonly argued that in Amazonia neither founding transcendence, nor God's eye or science's laws assure, with a decontextualized look, the stability of beings beyond the direct perception that an intentional subject may have. ${ }^{8}$

The second reason is that relations of predation and mastery are ambiguous and bi-directional, always at risk of being inverted. The owner-master figure is a Janus-faced one: "In the eyes of his children-pets, a protective father; in the eyes of other species (especially humans), a predatory affine" (Fausto 2008: 6). This is because "cannibal incorporation" is one of the main devices for accruing vital power in Amazonia (ibid.). Incorporation of alien subjects with other wills results in a magnification of selfhood. However, this effort remains partial at best because the person who incorporates-the master-is always at risk of losing his/her own perspective in the process of incorporating others. Likewise, those incorporated are, if not more powerful, always potentially able to overpower their masters.

To offer a common example, the acquisition of shamanic ${ }^{9}$ power is conceived of as a process of familiarization with non-human entities frequently associated with predation and cannibalism (e.g., the jaguar, the anaconda). When the shaman adopts these auxiliary spirits, he turns a relation of predation into one of control and protection, but the adoption remains ambivalent for it is never clear who controls whom (Fausto 2012: 229). That is, owners depend on the intentionality of those whom they incorporate and protect, but never fully control it. So while owners strive to tame these others who become their children, they must ensure that they preserve the subjectivity and perspective-the source of agency-of the latter so as not to put an end to their potency. The positional ambivalence between the terms is particularly evident in shamanic relations, as we shall see next.

\section{Shamanism}

It has been common for specialists of lowland South America to describe the region as one where coercive centralized power either does not exist or exists only temporarily (see, e.g., LéviStrauss 1944; Lowie 1948). But even if power is not centralized and stable, it is far from absent, especially if we widen the meaning of the term to include the "ability to exercise symbolic control over the material and ideal resources of the group": the powers of fertility and the power over life and death that often lie with shamans (Chaumeil 1988: 72). ${ }^{10}$ Any exploration of power and politics in Amazonia, therefore, has to deal with shamans, who mediate between the various collectives of beings and "regenerate species-life through ritual" (Descola 2013: 9).

Of particular bearing for our argument about legibility is the fact that Amazonian shamans possess the power of seeing, although their powers and ways of operating often remain invisible to others. For instance, shamans can typically diagnose the origin of the harmful darts they see in the bodies of patients and can therefore denounce by name the enemy shaman responsible for a death or affliction. Yet shamanism is shrouded in secrecy: shamans heal or harm thanks to 
their ability to establish relationships with invisible and powerful helper spirits. Their actions are concealed from public view, and their power defies ordinary control. They acquire their powers in faraway locales as they undertake apprenticeship travels that are kept secret.

But despite their ability to traffic with invisible powers while remaining opaque to others, shamans are by no means omnipotent or socially uncontrolled. ${ }^{11}$ Just like the Siberian shamans of hunting societies whose power is strictly dependent on their efficacy (Hamayon 1996: 81), the position of Amazonian shamans is characterized by existential precarity and social unpredictability. In the Siberian case, if a shaman's performance is no longer efficacious, he loses favor with his people. More importantly, he depends on the community to acquire the instruments of his power-his costume, drum, and other paraphernalia-in order to keep these instruments animated (ibid.). Similarly, among the Baruya of Papua New Guinea, the initiation of shamans is strictly controlled and coordinated by all members of the tribe (Descola and Lory 1982). For the most part, Amazonian shamans do not depend on a collectivity to acquire or exercise their power, yet they are subject to informal social control. Shamans are targets of suspicion even among their relatives, who can never be sure whether a closely related shaman may eventually turn against them. In some places, the suspicion of witchcraft is one of the few conditions that justify homicide (Descola and Lory 1982: 92; Dole 1973: 305; Heckenberger 2004: 180). The socially ambivalent and precarious position of Amazonian shamans more broadly reflects their composite make-up and subjective indeterminacy. As Rodgers (2002: 121) puts it: "The shaman is a multiple being, a micropopulation of shamanic agencies sheltering within a body: hence neither are his 'intentions' exclusively 'his', nor can he ever be certain of his own intentions' (as cited in Fausto 2008: 14). This has made some authors conclude that shamanic activity is experienced as an unpredictable form of 'unwilled', if transformative, predation gifted from others (Cepek 2015).

In sum, metahumans (and shamanic power is surely of a metahuman kind) are immensely powerful, but their powers are fleeting and unstable because their way of accruing and exerting power is multiplicatory and dispersive. In this part of the world, while the animistic cosmos is saturated with intentionality, no being can harness the resources necessary to stabilize the intentions of others. Shamans and spirit-beings can see more than others, and on this basis have powers to harm and heal; yet they themselves remain always vulnerable to counterattacks. Marked by constitutive ambiguity, the masters of life and death thus defy a view of absolute or unified agency. More importantly, they subvert the verticalization of relationships necessary to attain the degree of centralization that is characteristic of state formation.

Social relations in the OPS therefore present a series of obstacles to the emergence of state legibility and to the systematization of mind reading that we call mind legibility. Both forms of legibility require a unification of points of view that makes different points of view comparable. This unification, by necessity, is based on (1) a privileged vantage point from where to see and stably control and read others; (2) technologies for simplifying social reality into a map; and (3) social institutions that allow for such vantage points and technologies. The next section briefly touches on the emergence of those social institutions and hints at the fundamental correlation between state legibility and mind legibility.

\section{The Correlations of State Legibility and Mind Legibility}

What really distinguishes the state of the OPS from what we commonly understand as 'the state' is that there may be dependence, but it does not turn into stable domination. In Amazonia, mastery and shamanism build a social complex in which it is impossible to permanently fix and subdue others' intentions. Usually, no being can make another being into a 'legible object' —and 
when it can, the relationship cannot be stabilized, that is, sustained in space and time. The people of what is typically called 'the state', however, are forced to do exactly that, as stable hierarchies and command relations require a careful management of intentions protracted in space and time. A top-down order means the imposition of one intention over another; and bottom-up submission means to accept another's intention over one's own. To do so, it must be possible to handle others' intentions and compare their intentions with their actions: this is precisely where legibility - both of state and of mind-comes in. State legibility and mind legibility impact on the ways in which intentions are attributed, fixed, and compared. In the remainder we briefly outline the correlations between state and mind legibility, specifically with regard to intention management (for more details, see Buitron and Steinmüller, forthcoming).

To make something 'legible' means to use a script through which an object can be captured and manipulated. The objectification of that which is legible is particularly obvious when dealing with projects of state legibility: the purpose of state legibility is to make particular contours of a population visible and recognizable to a center. These contours are simplified so as to create a 'map' of the population, which can be used to manage and exploit the same population (e.g., for taxation or conscription). The 'governors' at the center can 'read' a population using particular tools of legibility (census, registers, maps, etc.). They can then make use of those tools for purposes of extraction and violence. Indeed, the knowledge governments have of their populations is of necessity superficial, for if each subject would be known in its multiplicity and diversity, it would defeat the purpose of centralized legibility. The government knows just enough about the population to be able to manage it. The 'governed', in contrast, cannot 'read' the center in the same way: each subject knows only very little about the government's representatives, other than that their actions have a powerful impact. The result is what David Graeber (2012: 105) has called "lopsided structures of the imagination." In other words, the unintended consequence of projects of state legibility is the promotion of projects of mind legibility by the population.

Such 'lopsided structures' are typical of situations where there are huge differences in power, for instance, when women empathize with men, rather than men with women, or when ordinary people try to understand the intentions of government officials, rather than the reverse. Graeber (2012) extends this insight to what he calls 'dead zones of the imagination', a general theory of bureaucracy whereby organizations limit empathy so as to enable violence. Such 'dead zones' are based on not interpreting the intentions of others while subjecting them to control. The fundamental imbalance in empathy and imagination leads to new ways of public mind reading, not only in vertical relations (between inferiors and superiors), but also in horizontal relations (between the governed). Projects of state legibility generally are based on new concentrations of humans, animals, and plants, basically, "multispecies resettlement camps" (Scott 2017: 18). While camps are practical for the purpose of government, the crowded environment is also ideal for the spread of parasites, viruses, and germs. Crowding, violence, and disease thus accentuate the challenges for human cooperation that arise in resettlement camps. Subject populations often simply took to their feet to avoid these challenges and created "escape formations" at the peripheries of the new states (ibid.).

Aside from submission and escape, one essential corollary of living inside legible and crowded camps are new forms of collective and shared means to make intentions public, so as to manipulate the conditions for co-existence. This is fundamentally due to problems of scale and emerging division of labor and can be seen clearly in new forms of intention management that seek not only to align the intentions of others (as would be the case in a political regime where the agency of others is of value), but also to subdue them in an effort to make them exploitable. These are common challenges for political regimes overseeing populations in grid structures and camps: the problems to be solved are who turns up to work, how their productivity can be quantified, what to do about free riders, and so on. In such scenarios, the ability to predict and 
control the intentions of others is often associated with the threat of violence. By contrast, it is striking that in societies where people do not have the means (or even care) to make others systematically legible, violence may be rampant but is never used to support command (see, e.g., Rubenstein 2012: 60).

The concentration of humans (and animals and plants), along with higher levels of interdependence between humans, creates pressure to render intentions public and legible-whether or not there is direct intervention by agents of the state. Similar processes are observable when modern nation-states enforce policies of sedentarization through rural settlement or village formation among previously mobile forest dwellers. Such "efforts at domestication" (Scott 1998: 184) aim to make mobile and peripheral populations legible — visible and clear-while molding their landscape to the state's techniques of observation (ibid.: 82). But while this is happening, it appears that new nucleated settlements and villages, understood as a specific mode of social organization related to processes of state formation, trigger similar efforts among those who find themselves resettled (see, e.g., Stasch 2013)

\section{Conclusion}

Freud (1920: 246-247) famously claimed that psychoanalysis implies a decentering of humanity comparable to Copernicus's astrology, and Darwin's theory of evolution. Perhaps the OPS is a fourth revolution in this series-Sahlins (2017b) does indeed call for "something like a Copernican revolution" in the abstract to his essay. Just as Copernicus, Darwin, and Freud had dethroned humanity, anthropologists today need to accept the relative marginality of the human. Sahlins proposes exactly that when he points to the universal subordination of humanity to metahumans, the owners of nature. The main difference with Copernicus, Darwin, and Freud is that their revolutions created the framework for modern naturalism that paradoxically allowed for human minds to preside over inanimate matter, whereas Sahlins uses animism-the forces of life-to radically decenter humanity and nature.

What he ignores, however, is that metahumans are not transcendent gods, and do not know or prevail over everything. The metahuman beings of the OPS are not omniscient and omnipotent like the God of the Christian tradition, the God that became the transcendent measurement of the world and informed the opposition between mind and flesh, which in turn was the basis of the cosmology of Western science and sociology, as Sahlins himself has famously argued elsewhere (see Sahlins et al. 1996). Only an immeasurably transcendent God like this one could know the world in the manner of the panopticon's prison guard, whereas in the myths of the Greeks and the rituals of the Amazonian and Siberian hunters, it is still possible to hide from the gods. We suggest that Sahlins inadvertently smuggles the knowledge of this Western deity into his characterization of the metahuman persons of the OPS. This Western deity appears like a ghost between the letters written and read, and cannot be understood without the powers that legibility affords: specifically, the centralization of perspectives and the systematization of mind reading. Yet the powers of writing and the legibility effects of agriculture, sedentism, and domestication are largely absent from the Amazonian worlds we have discussed above. Shamans can see a lot, but ultimately they can never centralize perspectives in the manner necessary for agents of state legibility. And Amazonian owner-masters always aim to familiarize and incorporate others, but in doing so they can never occupy a stable vantage point over their prey and thus 'objectify' it, which would be necessary to make their minds 'legible' and thus available to public inspection. With the example of Amazonian owners, we have proposed that metahuman persons in decentralized and stateless societies know a lot, but they are not omniscient. Metahumans are powerful, too, but they are not 
omnipotent. And while metahuman persons sometimes set the rules of human behavior, they do not always stand above the rules. To the contrary, they need humans to observe these rules, lest they (the metahumans), cease to exist (for a similar point, see Howell 1989: 118).

This paradox of rule following, we suggest, is a core feature of those groups that provide the main case studies for the OPS. The seasons and the weather, fortune and disaster, life and death-all these obviously follow some rules that are opaque to the human mind, as are the metahumans associated with those forces. This fundamental opacity of life, however, does not mean that metahumans can form a state, if by 'state' we understand the 'standing order' imposed onto a population, not for a regular payment, but quite literally as an order to stand so as to be seen from one privileged vantage point. ${ }^{12}$

Rather than a Copernican revolution, we have a Copernican question: what kind of state is the government of metahumans? We have suggested here that making others legible is essential to all government, even to the government of the OPS. But among all possible modes of legibility, the objectification of entire populations from one single vantage point (that is, state legibility) and the representation and evaluation of individual minds (that is, mind legibility) are outliers that appear only in some states. They are absent from the OPS, and we have pointed to some of the mechanisms that stand in the way of a centralization of perspectives and a stabilization of mind reading. Neither humans nor metahumans can overcome these obstacles. Actually existing egalitarianism relies on the avoidance of state legibility, as well as the careful treatment and manipulation, but not erasure and total control, of other people's intentions.

\section{ACKNOWLEDGMENTS}

This article was first prepared for a workshop titled "State and Mind Legibility" held at the London School of Economics in June 2019. We are grateful to the participants and to our discussants for their contributions. We regret that Sahlins never saw our argument, and we can only hope that he would have found it legible and worthy of further debate. We dedicate this article to his memory.

NATALIA BUITRON is a Leverhulme Trust Early Career Research Fellow at the Oxford Department of International Development. She has done ethnographic fieldwork in Ecuadorian Amazonia, where she explores political selfhood, village/state formation, and moral change. Her current project is about indigenous sovereignties. She is the author of "Autonomy, Productiveness, and Community: The Rise of Inequality in an Amazonian Society" (Journal of the Royal Anthropological Institute, 2020).E-mail: natalia.buitron@qeh.ox.ac.uk

HANS STEINMÜLLER is an Associate Professor in the Department of Anthropology at the London School of Economics. He has done ethnographic fieldwork in Enshi (central China) and in the Wa Hills of the China-Burma border. He writes about attention, care, irony, and sovereignty, among other things. He is the author of Communities of Complicity: Everyday Ethics in Rural China (2013), and co-editor of Irony, Cynicism, and the Chinese State (2016). E-mail: j.steinmuller@lse.ac.uk 


\section{NOTES}

1. 'Egalitarianism' is potentially a misnomer because the term imputes a common purpose and practices of commensuration to socialities that are better described as a combination of autonomy, mutuality, and incommensurability (cf. Buitron and Steinmüller 2020).

2. Prior to the Hocart Lecture, Sahlins (2015) published a short manifesto containing some of the same ideas in Anthropology Today. The lecture was published in HAU (Sahlins 2017b) and as the first chapter in On Kings (Sahlins 2017a).

3. The 'theory' in question may be innate and modularized, learned individually, or developed through enculturation. Note also that 'simulationist' alternatives hold that mind-reading abilities are not underpinned by anything resembling a theory, but rather "an ability to project ourselves imaginatively into another person's perspective" (Carruthers and Smith 1996: 3).

4. Although perhaps this ability is not unique to humans. See, for example, Woodruff and Premack (1979) and the ensuing debate about whether primates have a theory of mind.

5. This is only a very brief summary of a very complex argument, and we do not deal with another important aspect: mastery is a relation internal to the constitution of animism's complex subjectsshaman and spirit, mother and child, woman and pet (Costa and Fausto 2019: 215).

6. This can also be framed in terms of a fundamental co-dependence or mutuality between the terms, evident even in the most unidirectional and hierarchical of behaviors such as rule giving. According to Howell (1989), the Chewong perceive rules as a gift from a particular group of superhumans. She compares this gifting of rules to the gifting of a song from a spirit-guide: "The spirit-guide needs the song to be sung as much as the human being needs to be given the song" (ibid.: 117).

7. In fact, the multiplicatory and unstable logic of mastery-ownership relations characterizes not only relations between humans or between humans and non-humans, but also relations internal to the non-human world.

8. An excellent illustration of this common observation is Overing's (1996: 77) description of the 'Piaoroa point of view': "There can be no stable hierarchy of power in the universe, for each world is immune to any sort of permanent state of affairs where agents from another world could dominate or govern agency within it. No agent in the universe, or groups of agents, including humans, can acquire a sufficient means to violence that would allow for the subjugation of others. Thus there can be no victors and vanquished in any absolute sense. The best that humans can do is to achieve equal relations in their often-dangerous dealings with beings of other spaces and other times."

9. Our main focus is lowland South American shamanism, broadly defined as a technique of trance induced via sophisticated use of hallucinogens whereby the shaman (or his/her soul) establishes privileged relations with spirit familiars or assistants in other cosmic domains (typically invisible) marked by distinct modes of intersubjective communication. Even in the region, there are different versions of shamanisms. Hugh-Jones (1996) writes about horizontal and vertical ideal types associated with more egalitarian versus more hierarchical societies respectively, although they may also be seen as transformations of the shamanic function (Viveiros de Castro 2002: 470-472). We highlight mostly aspects associated with horizontal shamanisms (widespread also in ranked societies) and characterized by their performative, individualistic, and ambivalent features-their power to heal is also their power to kill.

10. Recent conceptualizations of power in lowland South America have moved away from the implicitly negative characterization of power, as something that Amerindians strive to eject to block the emergence of the state, inherited from Clastres (1989), whose influence on Scott's work in Southeast Asia and generally on political anarchist theory is well known. Studied in its own right, power is now associated with the creative capacities of masters and the life-giving techniques that enable or subtract well-being, the reason why it is also studied in relation to shamanic activity rather than chiefship (e.g., Descola 1988; Overing 2012; Santos Granero 1986, 1993).

11. Ritual specialists who entertain contact with spirit familiars are even less powerful in other animistic contexts, as in the highlands of Southeast Asia, for example. Gibson (2019:240) illustrates a case of "mystical empiricism" among the Buid of Mindoro in the Philippines through group séances that take 
place when people summon their spirit familiars so as to create an "intersubjectively validated picture of the spirit world." Participation is truly open access, and Gibson found that "virtually every adult man and many older women possessed a spirit familiar which could be summoned at will by chanting" (ibid.). Buid mediums thus do not have privileged access to the spirit world nor do they exhibit charismatic authority.

12. Regarding this 'standing order', it is interesting to note that the etymology of 'state' in English (as well as French état, German Staat, Italian stato, and Spanish estado) goes back to Old French estat 'position, condition; status, stature, station', and Latin status 'a station, position, place; way of standing, posture; order, arrangement, condition', which is the past participle stem of Latin stare 'to stand', based on Proto-Indo-European sta-'to stand, make or be firm'. The standing army, as well as the landed estate, therefore share not only a common etymology, but also the core feature of a population standing, and thus being visible and legible from one vantage point.

\section{REFERENCES}

Astington, Janet Wilde. 2006. “The Developmental Interdependence of Theory of Mind and Language." In Roots of Human Sociality: Culture, Cognition, and Human Interaction, ed. N. J. Enfield and Stephen C. Levinson, 179-206. Oxford: Berg.

Astuti, Rita. 2012. "Some after Dinner Thoughts on Theory of Mind.” Anthropology of this Century 3. http://aotcpress.com/articles/dinner-thoughts-theory-mind/.

Buitron, Natalia, and Hans Steinmüller. 2020. “The Ends of Egalitarianism.” L'Homme 236 (3): i-xxxvi.

Buitron, Natalia, and Hans Steinmüller. Forthcoming. "Governing Opacity: The Politics of Intentions and Legibility." Ethnos.

Carey, Matthew. 2017. Mistrust: An Ethnographic Theory. Chicago: HAU Books.

Carruthers, Peter, and Peter K. Smith. 1996. "Introduction." In Theories of Theories of Mind, ed. Peter Carruthers and Peter K. Smith, 1-8. Cambridge: Cambridge University Press.

Cepek, Michael. 2015. "Ungrateful Predators: Capture and the Creation of Cofán Violence." Journal of the Royal Anthropological Institute 21 (3): 542-560.

Chaumeil, Jean-Pierre. 1988. "Chamanisme, rituel et pouvoir (exemples amazoniens)" [Shamanism, ritual, and power (Amazonian examples)]. Schweizerische Amerikanisten-Gesellschaft 52: 71-76.

Christian, William A., Jr. 1989. Person and God in a Spanish Valley. Rev. ed. Princeton, NJ: Princeton University Press.

Clastres, Pierre. 1989. Society Against the State: Essays in Political Anthropology. Trans. Robert Hurley with Abe Stein. New York: Zone Books.

Costa, Luiz, and Carlos Fausto. 2019. "The Enemy, the Unwilling Guest and the Jaguar Host: An Amazonian Story." L'Homme 231-232: 195-226.

Danziger, Eve. 2013. “Conventional Wisdom: Imagination, Obedience and Intersubjectivity." Language \& Communication 33 (3): 251-262.

Déléage, Pierre. 2005. "Le chamanisme sharanahua: Enquête sur l'apprentissage et l'épistémologie d'un rituel" [Sharanahua shamanism: Inquiry into the apprenticeship and epistemology of a ritual]. $\mathrm{PhD}$ diss. EHESS.

Descola, Philippe. 1988. "La chefferie amérindienne dans l’anthropologie politique" [Amerindian chiefdom in political anthropology]. Revue française de science politique 38 (5): 818-827.

Descola, Philippe. 2012. "Beyond Nature and Culture: Forms of Attachment." HAU: Journal of Ethnographic Theory 2 (1): 447-471.

Descola, Philippe. 2013. Beyond Nature and Culture. Trans. Janet Lloyd. Chicago: University of Chicago Press.

Descola, Philippe, and Jean-Luc Lory. 1982. "Les guerriers de l'invisible: Sociologie comparative de l'agression chamanique en Papousie Nouvelle-guinée (Baruya) et en Haute-Amazonie (Achuar)" [The warriors of the invisible: Comparative sociology of shamanic aggression in Papua New Guinea (Baruya) and in the Upper Amazon (Achuar)]. L'Ethnographie 87-88 (2-3): 86-111. 
Dole, Gertrude. 1973. "Shamanism and Political Control among the Kuikuru." In Peoples and Cultures of Native South America: An Anthropological Reader, ed. Daniel R. Gross, 294-307. New York: Doubleday.

Duranti, Alessandro. 2008. "Further Reflections on Reading Other Minds." Anthropological Quarterly 81 (2): 483-494.

Duranti, Alessandro. 2015. The Anthropology of Intentions: Language in a World of Others. Cambridge: Cambridge University Press.

Fausto, Carlos. 2008. “Too Many Owners: Mastery and Ownership in Amazonia.” Trans. David Rodgers. Mana 4 (SE). http://socialsciences.scielo.org/scielo.php?script=sci_arttext\&pi $\mathrm{d}=$ S0104-93132008000100001.

Fausto, Carlos. 2012. Warfare and Shamanism in Amazonia. Trans. David Rodgers. New York: Cambridge University Press.

Feuchtwang, Stephan. 2001. Popular Religion in China: The Imperial Metaphor. London: Curzon Press.

Freud, Sigmund. 1920. A General Introduction to Psychoanalysis. Trans. G. Stanley Hall. New York: Boni and Liveright.

Gibson, Thomas. 2019. "From Tribal Hut to Royal Palace: The Dialectic of Equality and Hierarchy in Austronesian Southeast Asia." Anthropological Forum 29 (3): 234-248.

Graeber, David. 2012. "Dead Zones of the Imagination: On Violence, Bureaucracy, and Interpretive Labor. The Malinowski Memorial Lecture, 2006.” HAU: Journal of Ethnographic Theory 2 (2): 105-128.

Graeber, David. and Marshall Sahlins. 2017a. "Introduction: Theses on Kingship." In Graeber and Sahlins 2017b, 1-22.

Graeber, David, and Marshall Sahlins. 2017b. On Kings. Chicago: HAU Books.

Groark, Kevin P. 2008. "Social Opacity and the Dynamics of Empathic In-Sight among the Tzotzil Maya of Chiapas, Mexico." Ethos 36 (4): 427-448.

Hamayon, Roberte N. 1996. "Shamanism in Siberia: From Partnership in Supernature to Counter-power in Society." In Thomas and Humphrey 1996, 76-89.

Heckenberger, Michael. 2004. “The Wars Within: Xinguano Witchcraft and Balance of Power." In In Darkness and Secrecy: The Anthropology of Assault Sorcery and Witchcraft in Amazonia, ed. Neil L. Whitehead and Robin Wright, 179-201. Durham, NC: Duke University Press.

Howell, Signe. 1989. Society and Cosmos: Chewong of Peninsular Malaysia. Chicago: University of Chicago Press.

Hugh-Jones, Stephen. 1996. "Shamans, Prophets, Priests and Pastors." In Thomas and Humphrey 1996, 32-75.

Hultkrantz, Åke. 1961. “The Owner of the Animals in the Religion of North American Indians.” In The Supernatural Owners of Nature, ed. Åke Hultkrantz, 53-64. Stockholm: Almqvist \& Wiksell.

Keane, Webb. 2008. "Others, Other Minds, and Others' Theories of Other Minds: An Afterword on the Psychology and Politics of Opacity Claims.” Anthropological Quarterly 81 (2): 473-482.

Keane, Webb. 2016. Ethical Life: Its Natural and Social Histories. Princeton, NJ: Princeton University Press.

Lévi-Strauss, Claude. 1944. “The Social and Psychological Aspect of Chieftainship in a Primitive Tribe: The Nambikuara of Northwestern Mato Grosso." Transactions of the New York Academy of Sciences 7 (1): $16-32$.

Lowie, Robert H. 1948. "Some Aspects of Political Organization among the American Aborigines." Journal of the Royal Anthropological Institute of Great Britain and Ireland 78 (1-2): 11-24.

Luhrmann, T. M. 2020. “Thinking about Thinking: The Mind's Porosity and the Presence of the Gods." Journal of the Royal Anthropological Institute 26 (S1): 148-162.

Luhrmann, Tanya Marie, Rita Astuti, Joel Robbins, et al. 2011. "Toward an Anthropological Theory of Mind." Suomen Antropologi: Journal of the Finnish Anthropological Society 36 (4): 5-69.

Overing, Joanna. 1996. "Who Is the Mightiest of Them All? Jaguar and Conquistador in Piaroa Images of Alterity and Identity." In Monsters, Tricksters, and Sacred Cows: Animal Tales and American Identities, ed. A. James Arnold, 50-79. Charlottesville: University of Virginia Press. 
Overing, Joanna. 2012. "Society against the Tyrant: Power, Violence and the Poetics of an Amazonian Egalitarianism." In Contesting the State: The Dynamics of Resistance and Control, ed. Angela Hobart and Bruce Kapferer, 55-86. Wantage: Sean Kingston Publishing.

Robbins, Joel, and Alan Rumsey. 2008. "Introduction: Cultural and Linguistic Anthropology and the Opacity of Other Minds." Anthropological Quarterly 81 (2): 407-420.

Rodgers, David. 2002. "A soma anômala: A questão do suplemento no xamanismo e menstruação ikpeng" [An abnormal sum: The question of supplementation in Ikpeng shamanism and menstruation] Mana 8 (2): 91-125.

Rubenstein, Steven Lee. 2012. "On the Importance of Visions among the Amazonian Shuar." Current Anthropology 53 (1): 39-79.

Sahlins, Marshall. 1972. “The Original Affluent Society." In Stone Age Economics, 1-39. London: Tavistock. Sahlins, Marshall. 2013. "Foreword." In Descola 2013, xi-xiv.

Sahlins, Marshall. 2014. “On the Ontological Scheme of 'Beyond Nature and Culture." HAU: Journal of Ethnographic Theory 4 (1): 281-290.

Sahlins, Marshall. 2015. "An Anthropological Manifesto: Or the Origin of the State." Anthropology Today $31(2): 8-11$.

Sahlins, Marshall. 2017a. “The Original Political Society." In Graeber and Sahlins 2017b, 23-64.

Sahlins, Marshall. 2017b. “The Original Political Society: The 2016 Inaugural A. M. Hocart Lecture.” HAU: Journal of Ethnographic Theory 7 (2): 91-128.

Sahlins, Marshall, Thomas Bargatzky, Nurit Bird-David, et al. 1996. “The Sadness of Sweetness: The Native Anthropology of Western Cosmology [and Comments and Reply].” Current Anthropology 37 (3): $395-428$.

Santos Granero, Fernando. 1986. "Power, Ideology and the Ritual of Production in Lowland South America." Man (n.s.) 21 (4): 657-679.

Santos Granero, Fernando. 1993. "From Prisoner of the Group to Darling of the Gods: An Approach to the Issue of Power in Lowland South America." L'Homme 33 (126-128): 213-230.

Scott, James C. 1998. Seeing Like a State: How Certain Schemes to Improve the Human Condition Have Failed. New Haven, CT: Yale University Press.

Scott, James C. 2009. The Art of Not Being Governed: An Anarchist History of Upland Southeast Asia. New Haven, CT: Yale University Press.

Scott, James C. 2017. Against the Grain: A Deep History of the Earliest States. New Haven, CT: Yale University Press.

Sprenger, Guido. 2017. "Communicated into Being: Systems Theory and the Shifting of Ontological Status." Anthropological Theory 17 (1): 108-132.

Stasch, Rupert. 2008. "Knowing Minds Is a Matter of Authority: Political Dimensions of Opacity Statements in Korowai Moral Psychology." Anthropological Quarterly 81 (2): 443-453.

Stasch, Rupert. 2013. "The Poetics of Village Space When Villages Are New: Settlement Form as History Making in Papua, Indonesia." American Ethnologist 40 (3): 555-570.

Thomas, Nicholas, and Caroline Humphrey, eds. 1996. Shamanism, History, and the State. Ann Arbor: University of Michigan Press.

Viveiros de Castro, Eduardo. 2002. "Xamanismo e sacrificio" [Shamanism and sacrifice]. In A inconstância da alma selvagem, e outros ensaios de antropologia [The inconsistency of the savage soul, and other anthropological essays], 459-472. São Paulo: Cosac \& Naify.

Wang, Haicheng. 2014. Writing and the Ancient State: Early China in Comparative Perspective. New York: Cambridge University Press.

Wellman, Henry M., David Cross, and Julanne Watson. 2001. "A Meta-Analysis of Theory-of-Mind Development: The Truth about False Belief." Child Development 72 (3): 655-684.

Woodruff, Guy, and David Premack. 1979. "Intentional Communication in the Chimpanzee: The Development of Deception." Cognition 7 (4): 333-363. 